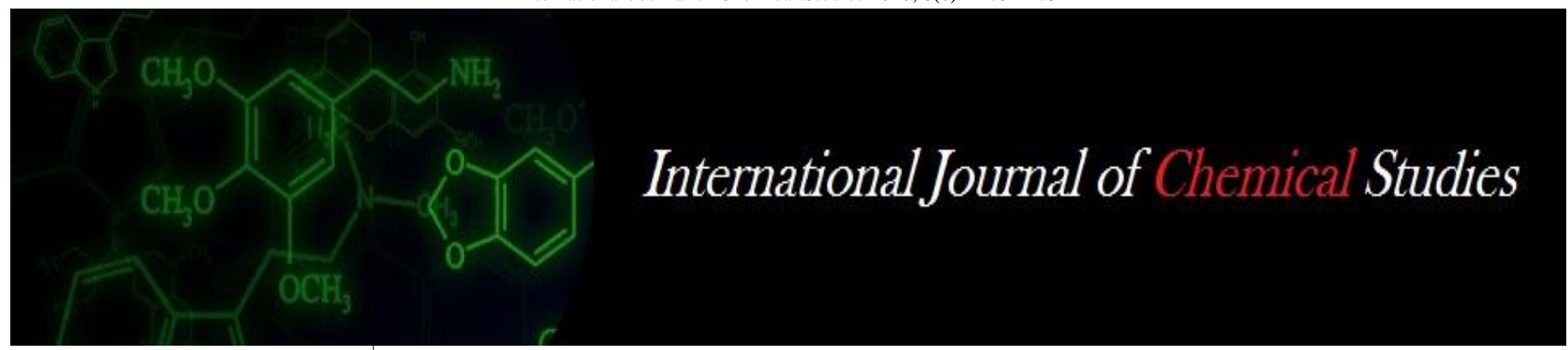

P-ISSN: 2349-8528

E-ISSN: 2321-4902

www.chemijournal.com

IJCS 2020; 8(6): 1173-1175

(C) 2020 IJCS

Received: 23-09-2020

Accepted: 27-10-2020

Arshveer Singh Brar

Department of Agronomy,

School of Agriculture, Lovely

Professional University,

Jalandhar, Punjab, India
Corresponding Author: Arshveer Singh Brar

Department of Agronomy,

School of Agriculture, Lovely

Professional University,

Jalandhar, Punjab, India

\section{Herbicide residue in soil, crop produce and in underground water: A review}

\section{Arshveer Singh Brar}

DOI: https://doi.org/10.22271/chemi.2020.v8.i6q.10922

\begin{abstract}
At present, herbicides are widely used in agriculture all over the world because of expanding input cost, decision of use of herbicides because of quick weed control in cropped and non-cropped areas. In India, herbicides are used up to $30 \%$ during the recent 10 years. Herbicides kill the weeds but they also effect on soil, crop, underground water, plants, animals, humans and cause pollution of soil and environment. Some herbicides are reside in the soil and water and they effect on the microbes in soil, effect on the next crop, reside in grain and straw, damage flora and fauna of water and spread the diseases. The herbicides monitored were Fluroxypyr, Methabenzthiazuron, Imazamethabenz, Linuron, Aclonifen, Diclofopmethyl, Pendimethalin, Propyzamide, Trifluralin, Metolachlor, Chlortoluron, 2,4-DB, MCPA, Atrazine, Simazin, Terbuthylazine, Metoxuron, Monuron, Diuron, Metobromuron, Tribenuron-methyl, Mecoprop, Chloroxuron, 2,4,5-TB, Neburon, Prometryn, Metribuzin, Cyanazin etc. All of them are responsible for toxicity to humans and animals as well as these leave residues in soil and crop produce.
\end{abstract}

Keywords: Herbicide, Water, Crop, Depletion, Soil, Residue

\section{Introduction}

Herbicides are the chemical compounds that is phytotoxic to weed and safe to crop. They derived from two words i.e. herbs mean grass or weed and cide mean suicide that is kill the weeds or herbs. The long term use of herbicides results in resistance to weeds, shift in weed flora, residue in soil, water pollution and health hazard to humans. The use of herbicide at global level $44 \%$ followed by insecticide $22 \%$, fungicide $27 \%$, others $7 \%$ (Sondhia Shobha 2014) ${ }^{[24]}$. 2,4-D was first herbicide used in 1942 by Zimmerman and Hitchcoak on broadleaf weeds in cereals during 1946.

A. Herbicide residue in soil: The period of time that a herbicide stays dynamic in soil, water is called persistence of herbicide. The continous and unpredictable utilization of herbicide in different crops may result in harmful buildup of herbicide in soil, underground water and crop produce. Adsorption and aggregation of herbicide in soilfavor its perseverance. The leftover action of herbicides might be negative to the climate, requiring examination of the diligent buildups in the dirt and water (Bzour et al. 2019) ${ }^{[4]}$. A few herbicides have a long leftover. The lingering is not equivalent to the half-life. In spite of the fact that the measure of synthetic in the dirt may separate to a large portion of the first sum quickly, what remains can be industrious for significant stretches, for example sulfonylureas.

\section{Classification of herbicide based on persistence}

1. Short persistent: They persist in the soil less than one month. e.g. Phenoxy group.

2. Medium persistent: They persist in soil from one to three month. e.g. Alachlor, Pendimethalin, metalachlor.

3. Highly persistent: They remain in the soil from three to tweleve month. e.g. Triazine, Substituted urea group. 
Table 1: Herbicide persistence in soil

\begin{tabular}{|c|c|}
\hline Name of herbicide & Reside in soil (days) \\
\hline Metribuzin & $20-100$ \\
\hline Thiobencarb & $28-60$ \\
\hline Atrazine & $45-90$ \\
\hline Butachlor & 100 \\
\hline Metolachlor & $40-190$ \\
\hline Dithiopyr & $90-150$ \\
\hline $2,4-D$ & $45-90$ \\
\hline Oxadiazon & $56-125$ \\
\hline Metoxuron & 80 \\
\hline Oxyflourfen & $60-80$ \\
\hline Pendimethalin & $60-200$ \\
\hline Imazethapyr & $90-240$ \\
\hline Fluzifop-p-butyl & $30-90$ \\
\hline Pretilachlor & $30-60$ \\
\hline Tralcoxydim & $28-45$ \\
\hline Pyrazosulfuron-ethyl & $35-60$ \\
\hline Imazosulfuron & 60 \\
\hline Alachlor & $60-80$ \\
\hline Isoproturon & $90-120$ \\
\hline
\end{tabular}

Source: Sondhia Shobha $2014^{[23]}$

Bzour et al. $2019^{[4]}$ observed that IMI (Imidazolinone) herbicides are persistent in the soil, and their residues remain for up to 85 days after application in rice.

Helander et al. $2019^{[10]}$ noticed that the soil contain $0.91 \mathrm{mg} / \mathrm{kg}$ glyphosate and potato tuber $0.02 \mathrm{mg} / \mathrm{kg}$ glyphosate. Sondhia $2019^{[23]}$ reported that the half-lives of herbicide in soil was 57-71 days ofimidazoline, 13-60 days forphenylureas, 13-147 days sulfonylurea, 12-58 days triazines, 50-60 days chloroacetinalides, 12-77 days dinitroanilines, 19-29 days diethylether, 19-24 days for thiocarbamates. Mahanta et al. 2019 noticed that the butachlor and pretilachlor in rice at application of 1.5 and $0.75 \mathrm{~kg} / \mathrm{ha}$ and they persist in soil up to 30 days and they are also present in grain and straw.

\section{B. Effect of different herbicide on surface and groundwater}

Luo et al. $2019^{[13]}$ observed that groundwater is a fundamental freshwater asset for drinking water creation in numerous districts of the world. Groundwater contamination are of two kinds i.e. common and antropogenic.

In any case, groundwater quality is progressively undermined by natural micropollutants, particularly pesticides. 2,4dichlorophenoxyacetic acid (2,4-D), 2,6-dichlorobenzamide (BAM), mecoprop-p (MCPP) and bentazone were bought from Sigma-Aldrich (USA). These mixes have a high ecological versatility (high solvency) and subsequently are as often as possible identified in groundwater. Exhaustion of groundwater assets and proceeded with decrease in groundwater quality is a reason for concern since enormous human population around the globe utilizes groundwater as a source of drinking water. Groundwater contamination because of natural pollutants especially of insecticides, herbicides, and foreign substances is of developing concern. Contamination because of inorganic toxins, for example, arsenic and other heavy metals explored with specific accentuation on locales that have detailed a fundamentally higher frequency of these poisons in groundwater. As herbicides are compound in nature and in this way inordinate and rehashed use may present buildup issues, phytotoxicity to edit plants, leftover impact on defenseless between crops or succeeding yields or nontargets life forms and eventually wellbeing risks because of amassing of herbicide deposits in the dirt, crop produce and ground water (Kurwadkar 2019) ${ }^{[11]}$. Numerous herbicides are found as bound deposits which make them inaccessible to the objectives as well as dirtying the dirt environment in various manners. There is a need to screen herbicide deposits in different items to survey development, biomagnifications and bioaccumulation of buildups and unfavorable impacts assuming any Bruggen et al. $2018^{[3]}$ showed that glyphosate accumulate in the environment and carcinogenic to humus and breakdown the aminomethyl/phosphonic acid(AMPA) in soil, water and toxic to micro amd macro organism.

Rendom et al. 2017 revealed that glyphosate present in bottle drinking water, ground water, urine of subsistence farmers.

Sodhia 2009 examied that the maximum concentration ofdmetsulfuron from 0-20 cm depth in both sandyloam and clay loam soil. Cohem et al. 2009 noticed that DBCP (1,2dibromo-3-chloropropane) appear mostly in well water and value within $5 \mu \mathrm{g} / \mathrm{L}$ in contaminated well. Sagratini et al. 2007 [19] observed that the most commonly detected herbicides were Atrazine, Fluroxypyr, Metolachlor, and Terbuthylazine in irrigation wells and toxicity to crop. Mamy et al. $2005^{[14]}$ examined that the low amount of metazachlor, sulcotrione, metamitron, trifluralin, glyphosate and its metabolites residue in soil after application of 140 days. Chand et al. 2004 [7] remarked that the halosulfuron methyl (HM) residue effect on succeeding crops like black gram, maize, cucumber after sugarcane. Rice et al. $2003^{[18]}$ observed thatmetoalachlor and atrazine degradation is surface water and to evaluate the contribution of sediment to their dissipation.

Camazano et al. $2003^{[5]}$ observed that the atrazine and alachlor present in both surface and ground water and they pose to the human health.

\section{Effect on crop produce}

Table 2: Maximum residue limit (MRL) permitted in various field crops

\begin{tabular}{|c|c|c|}
\hline Crop & Herbicide & MRL \\
\hline \multirow[t]{7}{*}{ Rice } & 2,4-D & 0.1 \\
\hline & Butachlor & 0.5 \\
\hline & Oxyflourfen & 0.2 \\
\hline & Oxadiazon & 0.05 \\
\hline & Penoxsulam & 0.02 \\
\hline & Pyrazosulfuronethyl & 0.5 \\
\hline & Imazosulfuron & 0.5 \\
\hline \multirow[t]{2}{*}{ Wheat } & $2,4-\mathrm{D}$ & 2.0 \\
\hline & Ethoxysulfuron & 0.2 \\
\hline \multirow[t]{4}{*}{ Corn } & $2,4-\mathrm{D}$ & 0.05 \\
\hline & Simazine & 0.2 \\
\hline & Atrazine & 0.25 \\
\hline & MCPA & 0.01 \\
\hline \multirow[t]{7}{*}{ Sugarcane } & $2,4-\mathrm{D}$ & 0.05 \\
\hline & Simazine & 0.2 \\
\hline & Atrazine & 0.25 \\
\hline & Alachlor & 0.1 \\
\hline & Diuron & 0.2 \\
\hline & Metribuzin & 0.5 \\
\hline & Metalachlor & 0.1 \\
\hline Soybean & Clomazone & 0.05 \\
\hline \multirow{2}{*}{ Potato } & Trifluralin & 0.05 \\
\hline & Metribuzin & 0.6 \\
\hline Garlic & Clethodim & 0.5 \\
\hline \multirow[t]{3}{*}{ Onion } & Clethodim & 0.5 \\
\hline & Metalachlor & 0.1 \\
\hline & Cycloxydim & 3.0 \\
\hline Pea & Metalachlor & 0.3 \\
\hline \multirow[t]{2}{*}{ Tomato } & Diuron & 0.2 \\
\hline & Pendimethalin & 0.05 \\
\hline
\end{tabular}

Source: Walia 2018

Hatterman et al. $2017^{\text {[9] }}$ revealed that the glyphosate and dicamba injury to dry edible pea from $0-13 \%$, dry edible bean 


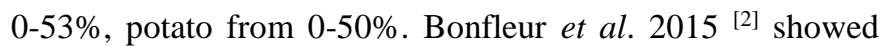
that the mixture of glyphosate and atrazine decreases the soil microbial biomass within 21 days. Sondhia $2013^{[21]}$ observed that the pendimethalin at harvest in tomato, cauliflower, radish $0.008,0.001,0.014$ milligram/gram respectively. Stempvoort et al. $2013^{[22]}$ revealed that the glyphosate and metabolite aminomethylphosphonic acid (AMPA) present in groundwater.

\section{Conclusion}

From this reviews, I concerned the herbicide are used to kill the weeds but they are reside in the soil and effect on the next crop, damage the soil flora and fauna. They spread the diseases and also effect on the water fishes and other fauna. They are directly or indirectly effect on the soil, crop and water. They effect on the population of microbes, type of soil, properties and chemistry of soil. They indirect effect on plant species, diversity of plants and wildlife. Overall study the herbicide kill the weeds and increase the productivity but they are great pose to human, plant, animals, environment etc.

\section{References}

1. Al-Rajab AL, Schiavon M. Degradationof 14Cglyphosate and aminomethyl phosphonicacid (AMPA) in three agricultural soils. Journal of Environmental Sciences 2010;22(9):1374-1380.

2. Bonfleur EJ, Tornisielo VL, Regitano BJ, Lavorenti A. The effects of glyphosate and atrazine mixture on soil microbial population and subsequent impacts on their fate in a tropical soil. Water Air Soil Pollution 2015;226:21.

3. Bruggen V, AHC He, Shin MM, Mai K, Jeong V, Finckh KC, Morris MR. Enviormantal and health effect of herbicide glyphosate. Science of total Enviormental 2018,255-268.

4. Bzour M, Zuki FM, Mispan MS, Jodeh S, Latif MA. Determination of the leaching potential and residues activity of imidazolinone herbicide in clear field rice soil using high performance liquid chromatography. Bulletin of environmental contamination and toxicology 2019;103:348-353.

5. Camazano M, Lorenzo LF, Martin MJ. Atrazine and alachlor inputs to surface and ground waters in irrigated corn cultivation areas of castilla-leon region, Spain. Environment monitoring and assessment 2003;105:11-24.

6. Correia FV, Moreira JC. Effects of glyphosate and 2,4-D on earthworms (Eiseniafoetida) in laboratory tests. Bull Environment Contamination Toxicological 2010;85:264268.

7. Chand M, Singh Samar, Dharam Bir, Singh N, Kumar V. Halosulfuron Methyl: A new post emergence herbicide in India for effective control of Cyperusrotundus in Sugarcane and its residual effects on the succeeding crops. Sugarcane Technology 2014;16(1):67-74.

8. Heydari A, Misaghi IJ. The impact of herbicides on the incidence and development of Rhozoctoniasolani Induced cotton seedling damping off. Plant diseases, 1998;82:110-113.

9. Hatterman Valenti H, Endres G, Jenks B, Ostlie M, Robinson A, Zollinger R et al. Defining glyphosate and dicamba drift injury to dry edible pea, dry edible bean, and potato. Horticulture technology 2017,27(4).

10. Helander M, Pauna A, Saikkonen K, Saloniemi L. Gyphosateresidue in soil affect crop plant germination and growth. Scientific reports nature research 2019;9:19653.
11. Kurwadkar S. Occurence and distribution of organic and inorganic pollutants in groundwater. Water environment research 2019,1-8.

12. Laitinen P, Ramo S, Siimes K. Glyphosate translocation from plants to soil- does constitute a significant proportion of residues in soil? Plant Soil 2007;300:51-60.

13. Luo Y, Atashgahi S, Comans NJ, Sutton NB, Rijnaarts HM. Influence of different redox conditions and dissolved organic matter on pesticide biodegradation is simulated groundwater system. Science of total environment 2019;677:692-699.

14. Mamy L, Barriuso E, Gabrielle B. Environmental fate of herbicides trifluralin, metazachlor, metamitron and sulcotrione compared with that of gyphosate, a substitute broad spectrum herbicide for different glyphosateresistant crops. Pest management science 2005;61:905916.

15. Meriles JM, Vargas Gil SS, Haro RJ, March GJ, Guzman CA. Glyphosate and previous crop residue effect on deleterious and beneficial soil-borne fungi from a peanutcorn-soybean rotations. Journal of Phytopathology 2006;154:309-316.

16. Marple EM, Al-Khatib K, Shoup D, Peterson ED, Claassen M. Cotton response to simulated drift of seven hormonal - type herbicide. Weed technology 2007;21:987-992.

17. Ritter WF, Scarborough RW, Chirnside AEM. Contamination of groundwater by triazines, metolachlor and alachlor. Journal of Contaminant Hydrology 1994;15:73-92.

18. Rice PJ, Anderson TA, Joel Coats R. Effect of sediment on the fate of metalachlor and atrazine in surface water. Environmental Toxicology and Chemistry 2004;23:11451155 .

19. Sagratini G, Ametisti M, Canella M, Volpini R. Well water in Italy: Analysis of herbicide residues as potential pollutants of untreated crops. Fresenius environmental bulletin 2007,18-8.

20. Shobha Sondhia. Leaching behaviour of metsulfuron in two texturally different soils. Environment Monitoring Assess 2009;154:111-115.

21. Sondhia S. Harvest time residues of pendimethalin in tomato, cauliflower, and radish under field conditions. Toxicological and environmental chemistry 2013;2:254259.

22. Stempvoort DR, Roy JW, Brown SJ, Bickerton G. Residues of herbicide glyphosate in riparian groundwater in urban catchments. Chemosphere, 2013;95:455-463.

23. Sondhia S. Herbicides residues in soil,water, plants and non-targeted organisms and human health implications: an Indian perspective. Indian journal of weed science 2014;46(1):66-85.

24. Tsai WT. A review on environmental exposure and health risks of herbicide paraquat. Toxicological \& Environmental Chemistry 2013;95(2):197-206.

25. Weaver MA, Krutz LJ, Robert M, Krishna N Reddy Effects of glyphosate on soil microbial communities and its mineralization in a Mississippi soil. Pest management science 2007;63:388-393.

26. Walia US. Weed management. Kalyani publishers, New Delhi. sWalia 2018 reported maximum residue limit (MRL) in crop produce (Table 2) 2018. 